\title{
Cysteine Peptidase Gene
}

National Cancer Institute

\section{Source}

National Cancer Institute. Cysteine Peptidase Gene. NCI Thesaurus. Code C28404.

Cysteine Protease Genes encode endopeptidases, inactivated by sulfhydryl reagents, that have a cysteine residue involved in the catalytic process. $(\mathrm{NCl})$ 